\title{
PENGARUH CORPORATE GOVERNANCE TERHADAP PENGUNGKAPAN LINGKUNGAN PERUSAHAAN BERSERTIFIKASI ISO-14001 DI INDONESIA
}

\author{
Sri Supatminingsih dan Monot Wicaksono \\ STIE AAS Surakarta \\ Email : patminingsihsri36@gmail.com
}

\begin{abstract}
ABSTRAK
Penelitian ini bertujuan untuk menguji pengaruh corporate governance terhadap pengungkapan lingkungan pada perusahaan yang terdaftar di Bursa Efek Indonesia. Struktur corporate governance dalam penelitian ini direpresentasikan oleh Dewan Komisaris (Ukuran dewan, jumlah komisaris independen, jumlah rapat komisaris), Komite Audit (Ukuran komite audit, keberadaan komite audit independen, jumlah rapat komite audit). Untuk variabel pengungkapan lingkungan menggunakan elemen ISO 14001. Berdasarkan sampel sejumlah 30 perusahaan bersertifikasi ISO 14001 pada tahun 2013 - 2014, setelah dilakukan analisis hasilnya menunjukkan. variabel proporsi anggota komite audit independen tidak berpengaruh terhadap pengungkapan lingkungan pada level signifikasi 0,05. Variabel jumlah rapat komite audit tidak berpengaruh terhadap pengungkapan lingkungan. Sedangkan variabel jumlah anggota dewan komisaris, proporsi anggota dewan komisaris independen, jumlah rapat dewan komisaris, jumlah anggota komite audit juga tidak berpengaruh terhadap pengungkapan lingkungan.
\end{abstract}

Kata Kunci : Corporate Governance, Pengungkapan Lingkungan, BEI, ISO 14001 


\section{PENDAHULUAN}

Pengungkapan lingkungan di Indonesia tidak diwajibkan oleh pihak pemegang otoritas, tetapi perusahaan secara sukarela mengungkapkan akuntansi lingkungan (voluntary environmental disclousure). Hal ini dilakukan untuk menjaga reputasi perusahaan dan terhindar dari penolakan masyarakat. Gray (1993) mengemukakan bahwa pengungkapan lingkungan merupakan bagian penting dari informasi sosial dalam laporan keuangan.

Corporate governance merupakan sistem tata kelola perusahaan yang menjelaskan hubungan antara berbagai partisipan dalam perusahaan yang menentukan arah kinerja perusahaan (FCGI, 2001). Isu mengenai corporate governance mulai mengemuka, di Indonesia pada tahun 1998 ketika Indonesia mengalami krisis yang berkepanjangan. Banyak pihak yang mengatakan lamanya proses perbaikan di Indonesia disebabkan oleh sangat lemahnya corporate governance yang diterapkan dalam perusahaan di Indonesia. Good Corporate Governance memiliki beberapa aspek penting yang harus diperhitungkan oleh kalangan bisnis. Aspek-aspek ini diharapkan mampu menjawab semua pertanyaan dalam perusahaan. Adanya keseimbangan hubungan antara organ-organ perusahaan di antaranya Rapat Umum Pemegang Saham (RUPS), komisaris, dan direksi. Adanya pemenuhan tanggung jawab perusahaan sebagai entitas bisnis dalam masyarakat kepada seluruh stakeholder. Adanya hak-hak pemegang saham untuk mendapat informasi yang tepat dan benar pada waktu yang diperlukan mengenai perusahaan. Adanya perlakuan yang sama terhadap para pemegang saham, terutama pemegang saham minoritas dan pemegang saham asing melalui keterbukaan informasi yang material dan relevan serta melarang penyampaian informasi untuk pihak sendiri yang bisa menguntungkan orang dalam (insider information for insider trading).

Penelitian ini mengacu pada penelitian yang dilakukan oleh Ho dan Wong (2001). Penelitian terdahulu dilakukan dengan setting di Hongkong, menggunakan sampel 610 chief financial officers (CFOs) dari perusahaan yang listing di Bursa Hongkong. Penelitian ini meneliti beberapa variabel atribut corporate governance antara lain proporsi dewan komisaris independen, keberadaan komite audit, keberadaan personal yang dominan (CEO/Chairman duality), dan prosentasi jumlah famili dalam komisaris. Variabel pengungkapan sosial menggunakan index pengungkapan relatif tertimbang. Hasil penelitian ini faktor yang berpengaruh terhadap luas pengungkapan sosial di Hongkong yaitu komite audit dan prosentase keluarga dalam komisaris berpengruh negatif terhadap pengungkapan sosial.

Berdasarkan latar belakang tersebut, maka penulis ingin mengetahui bagaimana mekanisme pelaksanaan corporate governance dapat mempengaruhi pengungkapan lingkungan yang dilakukan perusahaan-perusahaan yang terdaftar di Bursa Efek Indonesia. Oleh karena itu, penulis mengambil penelitian dengan judul "Pengaruh 


\section{Corporate Governance Terhadap Pengungkapan Lingkungan”.}

\section{Rumusan Masalah}

Berdasarkan latar belakang masalah yang telah diuraikan sebelumnya, rumusan masalah yang akan diteliti dalam penelitian ini adalah "Apakah Corporate Governance berpengaruh terhadap pengungkapan lingkungan pada laporan tahunan perusahaan publik yang tercatat di Bursa Efek Indonesia (BEI)?”. Sesuai dengan perumusan masalah tersebut, maka dijabarkan menjadi beberapa pertanyaan penelitian sebagai berikut:

1. Apakah ukuran dewan komisaris mempengaruhi pengungkapan lingkungan?

2. Apakah proporsi dewan komisaris independen mempengaruhi pengungkapan lingkungan?

3. Apakah jumlah rapat dewan komisaris mempengaruhi pengungkapan lingkungan?

4. Apakah ukuran komite audit mempengaruhi pengungkapan lingkungan?

5. Apakah proporsi komite audit independen mempengaruhi pengungkapan lingkungan?

6. Apakah jumlah rapat komite audit mempengaruhi pengungkapan lingkungan?

\section{TINJAUAN PUSTAKA}

\section{Pengungkapan Lingkungan}

Pengungkapan laporan keuangan diartikan oleh Evans (2003) sebagai berikut:
Disclosure means supplying information in the financial statement, including the statements themselves, the notes to the statements, and the supplementary disclosures associated with the statements. It does not extend to public or private statement made by management or information provided outside the financial statement.

Sesuai pengertian diatas FASB dalam Suwardjono (2005) pengambilan keputusan investasi dan kredit yaitu mengidentifikasi lingkup (scope) informasi yang dipandang bermanfaat untuk:

1) Statemen keuangan (financial statement).

2) Catatan atas statemen keuangan (notes to financial statement).

3) Informasi pelengkap (supplementary information).

4) Sarana pelaporan keuangan lain (other means of financial reporting).

5) Informasi lain (other information).

Pelaporan Keuangan mencakup semua informasi yang dapat disediakan manajemen yaitu komponen (1) sampai (4), tetapi pengungkapannya tidak diwajibkan oleh penyusun standar atau badan pengawas melalui peraturanperaturannya. Ikatan Akuntan Indonesia mewajibkan pengungkapan untuk komponen (1) dan (2), untuk komponen (3) sampai tingkat sangat merekomendasi (strongly recommended) (Suwardjono, 2005:578).

Dua jenis pengungkapan dalam hubungannya dengan persyaratan yang ditetapkan standar (Dorough, 1993, Na'im dan Rakhman, 2000), yaitu: 
a. Pengungkapan Wajib (mandatory disclosure)

b. Pengungkapan Sukarela (voluntary disclosure)

Secara konseptual, pengungkapan merupakan bagian integral dari pelaporan keuangan. Secara teknis, pengungkapan merupakan langkah akhir dalam proses akuntansi, yaitu penyajian informasi dalam bentuk seperangkat penuh statemen keuangan (Suwardjono, 2005:578). Pengungkapan merupakan jalan sederhana untuk memaksa manajemen memberikan informasi tentang perusahaan kepada pihak luar (Scott, 2006).

Indikator kinerja lingkungan yang saat ini bisa digunakan di Indonesia setidaknya ada empat jenis yaitu AMDAL (uji BOD dan COD air limbah), PROPER, ISO 14001 untuk manajeman lingkungan dan ISO 17025 untuk Sertifikasi Uji Lingkungan dan Indonesian Environmental Reporting Index. (IERI).

Pengungkapan lingkungan yang dipakai dalam penelitian ini diwakili dengan ISO 14001. ISO 14001 adalah sertifikasi manajemen lingkungan yang diperoleh perusahaan yang telah memenuhi standar internal dan dikeluarkan oleh pihak yang kompeten. Perusahaan yang berupaya untuk menerapkan ISO 14001 dianggap telah memiliki komitmen untuk memperbaiki secara terus menerus kinerja lingkungannya. ISO 14001 merupakan standar yang memadukan dan menyeimbangkan kepentingan bisnis dengan lingkungan hidup.(www. benefita.com). Standar internasional untuk sistem manajemen lingkungan telah diterbitkan pada bulan September 1996, yaitu ISO 14001 dan ISO 14004. Standar ini telah diadopsi oleh pemerintah RI ke dalam Standar Nasional Indonesia (SNI) menjadi SNI-19-14001-1997 dan SNI-1914001-1997.

\section{Elemen ISO 14001}

ISO 14001 dikembangkan dari konsep Total Quality Management (TQM) yang berprinsip pada aktivitas PDCA (Plan - Do - Check - Action). Elemen-elemen utama EMS akan mengikuti prinsip PDCA ini, yang dikembangkan menjadi enam prinsip dasar EMS, yaitu: kebijakan (dan komitmen) lingkungan, perencanaan, penerapan dan operasi, pemeriksaan dan tindakan koreksi, tinjauan manajemen, penyempurnaan terus-menerus. Keenam prinsip ISO 14001 Environmental Management System diatas dapat dibagi menjadi 17 elemen.

\section{Corporate Governance}

Organization for Economic Cooperation and Development (OCED) mendefinisikan Corporate Governance (Indra Surya dan Ivan Yustiavandana, 2006) sebagai :

Sekumpulan hubungan antara pihak manajemen perusahaan, board, pemegang saham, dan pihak lain yang mempunyai kepentingan dengan perusahaan. Corporate Governance juga mensyaratkan adanya struktur perangkat untuk mencapai tujuan 
dan pengawasan atas kinerja. Corporate Governance yang baik dapat memberikan rangsangan bagi board dan manajemen untuk mencapai tujuan yang merupakan kepentingan perusahaan, dan pemegang saham harus memfasilitasi pengawasan yang efektif sehingga mendorong perusahaan menggunakan sumber daya yang lebih efisien.

\section{Prinsip-prinsip}

OCED menyangkut lima bidang utama: hakhak para pemegang saham (shareholders) dan perlindungannya; peran para karyawan dan pihak-pihak yang berkepentingan (stakeholders) lainnya; pengungkapan (disclosure) yang akurat dan tepat waktu serta transparansi sehubungan dengan struktur dan operasi korporasi; tanggung jawab dewan (Dewan Komisaris maupun Direksi) terhadap perusahaan, pemegang saham, dan pihak-pihak yang berkepentingan lainnya. Atau secara ringkas prinsipprinsip tersebut dapat dirangkum sebagai: perlakuan yang setara (equitable treatment atau fairness), transparansi (transparency), akuntabilitas (accountability), dan responsibilitas (responsibility) (Tjager, et.al, 2003).

Struktur corporate governance yang berkaitan dengan struktur dewan perusahaan ada dua model, pertama model Anglo_Saxon atau single board model dan yang kedua model Continental Europe atau two-tier board system. (Arifin, 2005). Menurut Arifin (2005), perusahaan di Indonesia menerapkan two board system atau twotier board system seperti dianut perusahaa Amerika dan Inggris. Dalam model ini RUPS merupakan struktur tertinggi yang mengangkat dan memberhentikan dewan komisaris yang mewakili pemegang saham untuk melakukan kontrol atas manajemen. Dalam model ini hanya ada perbedaan dalam kedudukan dewan komisaris yang tidak langsung membawahi dewan direksi.

\section{a. Dewan Komisaris}

Sesuai dengan ketentuan pasal 108 Undang-undang No. 40 Tahun 2007 tentang Perseroan Terbatas (UU Perseroan Terbatas), komisaris bertugas mengawasi kebijaksanaan Direksi dalam menjalankan perseroan serta memberikan nasehat kepada Direksi. Kemudian dalam pasal 114 ayat 3 UU Perseroan Terbatas dikatakan bahwa komisaris wajib dengan itikad baik dan penuh tanggung jawab menjalankan tugas untuk kepentingan dan usaha perseroan.

Dewan Komisaris terdiri dari komisaris independen dan komisaris non- independen

\section{b. Komite Audit}

Ketentuan mengenai keberadaan komite audit diatur dalam Code of Good Corporate Covernance yang dikeluarkan oleh KNKG dan peraturan pencatatan BEJ. Dewan komisaris dapat membentuk komite audit yang terdiri dari anggota komisaris, eksternal auditor, dan 
internal auditor. Dalam Pedoman GCG Indonesia (KNKG, 2006) dijelaskan bahwa, Komite Audit bertugas membantu Dewan Komisaris untuk memastikan bahwa: (i) laporan keuangan disajikan secara wajar sesuai dengan prinsip akuntansi yang berlaku umum, (ii) struktur pengendalian internal perusahaan dilaksanakan dengan baik, (iii) pelaksanaan audit internal maupun eksternal dilaksanakan sesuai dengan standar audit yang berlaku, dan (iv) tindak lanjut temuan hasil audit dilaksanakan oleh manajemen.

\section{Pengaruh Corporate Governance terhadap lingkungan \\ Pengungkapan}

Menurut teori stakeholder, perusahaan bukanlah entitas yang beroperasi untuk kepentingan sendiri tetapi harus memberi manfaat bagi stakeholdernya (Gray et. al., 1994; Suhardjanto, et. al., 2008). Organisasi melaporkan lingkungannya karena salah satu kebutuhan informasi yang harus dipenuhi oleh pemangku kepentingan adalah informasi lingkungan. Dengan demikian, meski tidak diwajibkan perusahaan secara sukarela harus melaporkan tanggung jawab lingkungannya kepada publik.

Hubungan yang mungkin antara struktur corporate governance dan pengungkapan lingkungan bahwa, corporate governance digambarkan sebagai elemen penting untuk mengemudi di bidang tanggungjawab sosial. Corporate

$\begin{array}{llr}\text { Governance } & \text { menjadi } & \text { sumber } \\ \text { keunggulan } & \text { kompetitif } & \text { bagi } \\ \text { perusahaan di dalam dirinya } & \text { sendiri } \\ \text { (Shahin dan Zairi, 2007) } & \end{array}$

\section{Pengembangan Hipotesis}

Berdasarkan kerangka teori dan latar belakang diatas maka dikembangkan hipotesis

$H_{1}$ : Ukuran dewan komisaris berpengaruh positif terhadap pengungkapan lingkungan

$\mathrm{H}_{2}=$ Independensi Dewan Komisaris berpengaruh positif terhadap luas pengungkapan Lingkungan

$\mathrm{H}_{3}=$ Jumlah rapat Dewan Komisaris berpengaruh positif terhadap luas pengungkapan lingkungan

$\mathrm{H}_{4}$ : Ukuran Komite Audit berpengaruh positif terhadap luas pengungkapan lingkungan

$\mathrm{H}_{5}$ : Proporsi komite audit independen berpengaruh terhadap pengungkapan lingkungan

$H_{6}=$ Jumlah rapat Komite Audit

berpengaruh positif terhadap

pengungkapan lingkungan

\section{METODE PENELITIAN}

\section{Populasi, Sampel dan Teknik Pengambilan Sampel}

Populasi dalam penelitian ini adalah perusahaan yang tercatat di Bursa Efek Indonesia (BEI). Penelitian ini mengambil sampel perusahaan yang go public yang terdaftar di Bursa Efek Jakarta yang mengikuti Program ISO 14001. Pengambilan sampel secara purposif (purposive sampling), yaitu 
sampel ditarik sejumlah tertentu dari populasi dengan menggunakan pertimbangan tertentu.

Sampel data dipilih dengan metode purposive sampling dengan kriteria;

a. Perusahaan yang tercatat di Bursa Efek Indonesia tahun 2013 sampai dengan 2015.

b. Perusahaan tersebut mengungkapkan laporan lingkungan dalam laporan tahunan untuk periode akuntansi tahun 2009 dan 2010 yang dapat diakses melalui website Bursa Efek Indonesia (www.idx.co.id) atau situs masingmasing perusahaan tersebut.

c. Sampel dipilih 60 perusahaan, 30 bersertifikat ISO 14001 dan 30 perusahaan yang belum bersertifikat ISO. Jumlah tersebut didasarkan pada jumlah perusahaan yang bersertifikat ISO dan listing di BEI.

\section{Data dan Metode Pengumpulan Data}

Data yang digunakan dalam penelitian ini adalah data sekunder yaitu data perusahaan pada tahun 2013 dan 2014 yang diperoleh dari Indonesian Stock Exchange (IDX), Indonesia Capital Market Direktori (ICDM), dan dari masing-masing situs webnya.

Metode pengumpulan data yang akan digunakan untuk dianalisis dalam penelitian ini adalah metode dokumenter, karena data yang dikumpulkan adalah data sekunder dalam bentuk laporan keuangan perusahaan yang dijadikan subjek penelitian.

Pengukuran variabel dilakukan dengan menggunakan metode pada analisis konten sebagaimana dikembangkan oleh Beck, et. al, (2010). Dengan menggunakan teknik ini, apabila item informasi yang diteliti diungkapkan dalam laporan maka diberi skor 1, jika elemen tidak diungkapkan diberi skor 0 . Setelah masing-masing elemen diukur, skor dijumlahkan dan dibagi total elemen pengungkapan lingkungan.

\section{HASIL DAN PEMBAHASAN}

Pada bagian ini akan dibahas mengenai pengujian hipotesis dan pembahasan.

\section{Pengujian Hipotesis}

Untuk menguji hipotesis dalam penelitian ini, digunakan metode regresi linear berganda, uji signifikansi parameter individual, dan koefisien determinasi.

\section{a. Koefisien Determinasi}

Koefisien determinasi

mengukur seberapa jauh kemampuan model yang dibentuk dalam menerangkan variasi variabel dependen. Adapun besarnya nilai koefisien determinasi ditunjukkan pada tabel 9 sebagai berikut: 
Tabel 9

Hasil Uji Koefisien Determinasi

\begin{tabular}{|c|c|c|c|c|}
\hline Model & $\mathrm{R}$ & R Square & $\begin{array}{c}\text { Adjusted R } \\
\text { Square }\end{array}$ & $\begin{array}{c}\text { Std. Error of the } \\
\text { Estimate }\end{array}$ \\
\hline 1 & $.293^{\mathrm{a}}$ & .086 &.-022 & 7.002 \\
\hline
\end{tabular}

Sumber : Hasil Pengolahan Data

Hasil pengujian menunjukkan $\mathrm{R}^{2}$ sebesar 0,293 atau 29,3\%. Hasil ini menunjukkan bahwa 29,3\% besarnya pengungkapan lingkungan perusahaan yang terdaftar di Bursa Efek Indonesia disebabkan oleh mekanisme corporate governance (jumlah dewan komisaris, proporsi komisaris independen, jumlah rapat dewan komisaris, jumlah komite audit, proporsi komite audit independen, jumlah rapat komite audit), ukuran perusahaan dan tipe industri. Sedangkan $70,7 \%$ besarnya pengungkapan lingkungan disebabkan oleh variabelvariabel lain yang tidak diteliti dalam penelitian ini.

\section{b. Nilai $\mathbf{F}$}

Pengujian ini digunakan untuk mengetahui apakah semua variabel independen secara bersama dapat berpengaruh terhadap variabel dependen (goodness of fit model). Untuk pengujian ini dilakukan dengan menggunakan uji $\mathrm{F}$ ( $\mathrm{F}$ test). Adapun hasil pengujian secara simultan adalah sebagai berikut:

Tabel 10

Hasil Analisis Nilai F

\begin{tabular}{|l|l|r|r|r|r|}
\hline \multicolumn{2}{|c|}{ Model } & \multicolumn{1}{c|}{ Df } & $\begin{array}{c}\text { Mean } \\
\text { Square }\end{array}$ & \multicolumn{1}{c|}{ F } & \multicolumn{1}{c|}{ Sig. } \\
\hline \multirow{3}{*}{1} & Regression & 6 & .39 .028 & .796 & $.577^{a}$ \\
\cline { 2 - 6 } & Residual & 51 & 49.004 & & \\
\cline { 2 - 6 } & Total & 57 & & & \\
\hline
\end{tabular}

Sumber : Data diolah

Nilai $F$ regresi digunakan untuk mengetahui pengaruh secara simultan variabel independen terhadap variabel dependen. Pada tabel ...nilai F menunjukkan nilai 0,79 dengan signifikansi $0,577 . \quad$ Nilai $F$ memberikan hasil yang tidak signifikan. Hal ini berarti bahwa secara bersama-sama variabel independen tidak mempengaruhi variabel dependen. Kesimpulan yang diambil adalah variabel jumlah anggota dewan komisaris, proporsi anggota komisaris independen, jumlah rapat dewan komisaris, jumlah anggota komite audit, jumlah anggota komite audit independen, jumlah rapat komite audit, jenis industri dan ukuran perusahaan tidak mempengaruhi tingkat pengungkapan lingkungan. 


\section{c. Uji Signifikansi Parameter Individual (Uji Stastistik t)}

Uji t-statistik dilakukan untuk menyelidiki lebih lanjut mana diantara variabel bebas dan dua variabel kontrol yang berpengaruh signifikan terhadap pengungkapan sosial. Uji t-statistik dilakukan dengan melihat nilai signifikansi yang diperoleh masingmasing variabel. Hasil pengujian menunjukkan sebagai berikut:

Tabel 11

Hasil Analisis Regresi Berganda

Coefficients $^{\mathrm{a}}$

\begin{tabular}{|c|c|c|c|c|c|c|}
\hline \multicolumn{2}{|c|}{ Model } & \multicolumn{2}{|c|}{ Unstandardized Coefficients } & \multirow{2}{*}{$\begin{array}{c}\begin{array}{c}\text { Standardized } \\
\text { Coefficients }\end{array} \\
\text { Beta }\end{array}$} & \multirow[t]{2}{*}{$\mathrm{t}$} & \multirow[t]{2}{*}{ Sig. } \\
\hline & & B & Std. Error & & & \\
\hline \multirow[t]{7}{*}{1} & (Constant) & 6.156 & 3.597 & & 1.711 & .093 \\
\hline & $\mathrm{X} 1$ & .685 & .499 & .205 & 1.372 & .176 \\
\hline & $\mathrm{X} 2$ & -3.186 & 6.621 & -.067 & -.481 & .632 \\
\hline & $\mathrm{X} 3$ & -.080 & .213 & -.067 & -.375 & .709 \\
\hline & $\mathrm{X} 4$ & .526 & .877 & .115 & .600 & .551 \\
\hline & $\mathrm{X} 5$ & -.207 & .937 & -.036 & -.221 & .826 \\
\hline & X6 & .050 & .053 & .150 & .938 & .353 \\
\hline
\end{tabular}

a. Dependent Variable: Ytot

Sumber : Data diolah

PEMBAHASAN HASIL

\section{PENELITIAN}

Uji signifikansi masing-masing variabel diuraikan sebagai berikut :

a) Variabel jumlah anggota dewan komisaris (DK)

Hasil pengujian untuk variabel jumlah anggota dewan komisaris memiliki nilai probabilitas 0,507 lebih besar dari taraf signifikansi 0,05 . Hal ini berarti bahwa jumlah anggota dewan komisaris terbukti tidak berpengaruh positif terhadap pengungkapan lingkungan, sehingga hipotesis pertama (H1) yang menyatakan bahwa jumlah dewan komisaris berpengaruh positif terhadap pengungkapan lingkungan tidak dapat diterima (H1 ditolak).

Menurut

Undang-Undang

Perseroan Terbatas Nomor 40 Tahun 2007, Pasal 108 ayat (5) dijelaskan bahwa bagi perusahaan berbentuk perseroan terbatas, wajib memiliki paling sedikitnya 2 (dua) anggota dewan komisaris. Ketentuan ini mengatur bahwa jumlah anggota dewan komisaris harus lebih dari satu agar pelaksanaan tugas menjadi efektif. Jumlah anggota dewan komisaris dalam penelitian ini mempunyai rerata 5,25 yang berarti bahwa sebagian besar perusahaan telah memenuhi ketentuan Undang-Undang Perseroan Terbatas Nomor 40 Tahun 
2007, Pasal 108 tentang jumlah anggota dewan komisaris. Tetapi besarnya jumlah anggota dewan komisaris tidak menunjukkan bukti berpengaruh terhadap tingkat pengungkapan lingkungan.

Dewan Komisaris merupakan inti dari Corporate Governance yang ditugaskan untuk menjamin pelaksanaan strategi perusahaan, mengawasi manajemen dalam mengelola perusahaan, serta mewajibkan terlaksananya akuntabilitas. Pada intinya, Dewan Komisaris merupakan suatu mekanisme mengawasi dan memberikan petunjuk dan arahan pada pengelola perusahaan. (FCGI, 2002).

Jumlah dewan komisaris yang lebih besar, diharapkan pengalaman dan keahlian (experience and expertise) yang dimiliki oleh anggota dewan komisaris semakin meningkat, sehingga monitoring menjadi lebih baik (Akhtaruddin, et. al., 2009). Dengan beragamnya keahlian dan pengalaman diharapkan dewan komisaris memberi arahan atas pengelolaan perusahaan. Semakin baiknya pengelolaan perusahaan diharapkan pengungkapan lingkungan juga semakin luas sesuai harapan stakeholder.

Hal ini menunjukkan bahwa besar kecilnya jumlah anggota dewan komisaris tidak menjamin adanya mekanisme pengendalian yang lebih baik, karena bukan merupakan faktor penentu utama dari efektifitas pengawasan terhadap manjemen perusahaan. Efektifitas mekanisme pengendalian yang dilakuan oleh dewan komisaris tergantung pada nilai yang di anut, latar belakang budaya (Suhardjanto dan Novitasari, 2010). Untuk mencapai transparansi dan pengungkapan lingkungan level tinggi pembentukan dewan komisaris harus memperhatikan komposisi, kemampuan, dan integritas yang tinggi agar dapat mengendalikan dan mengarahkan manajemen untuk mencapai tujuan perusahaan.

Hasil penelitian ini bertentangan dengan hasil penelitian sebelumnya, penelitian Rouf (2010), Akhtaruddin, et. al., (2009), Buniamin (2008), Sembiring (2005) dan Sulastini (2007) yang menemukan adanya pengaruh yang positif signifikan antara jumlah anggota dewan komisaris dengan pengungkapan sosial dan lingkungan.

b) Variabel proporsi anggota komisaris independen (PROP_KI)

Hasil pengujian untuk proporsi anggota dewan komisaris independen memiliki tingkat signifikansi 0,475 lebih besar dari taraf signifikansi 0,05 . Hal ini menunjukkan bahwa komposisi dewan komisaris independen tidak terbukti berpengaruh positif signifikan terhadap pengungkapan lingkungan perusahaan. Hipotesis kedua $(\mathrm{H} 2)$ yang menyatakan bahwa komposisi dewan komisaris independen terhadap pengungkapan lingkungan tidak dapat diterima.

Proporsi anggota komisaris independen di Indonesia diatur dengan Ketentuan Bapepam dan Peraturan Bursa Efek Indonesia No. 1-A tanggal 14 Juli tahun 2004, di mana jumlah dewan komisaris independen minimal adalah $30 \%$. Ketentuan tersebut mensyaratkan jumlah minimal dewan komisaris independen. Jika proporsi komisaris independen semakin besar maka level pengungkapan lingkungan juga semakin tinggi. Komisaris independen menetapkan aturan kritis corporate 
governance dalam memberikan informasi lingkungan yang adequte (Akhtarudin,2010).

Pengujian terhadap variabel proporsi anggota komisaris independen menunjukkan bahwa variabel ini terbukti tidak berpengaruh positif signifikan terhadap pengungkapan lingkungan. Penemuan di atas memberikan arti bahwa komisaris independen yang dimiliki oleh perusahaan di Indonesia tidak berkontribusi terhadap pengungkapan lingkungan. Keberadaan dewan komisaris independen diharapkan dapat memberikan kontrol dan monitoring bagi manajemen dalam operasional perusahaan, termasuk dalam pelaksanaan dan pengungakapan aktivitas tanggung jawab sosial tidak berjalan seperti yang diharapkan. Ada kemungkinan komisaris independen mempunyai fungsi 'psedo' (semu) (Suhardjanto, 2008). Keberadaan dewan komisaris independen sematamata untuk memenuhi aturan yang berlaku, tidak disesuaikan dengan kebutuhan dan efetivitas organisasi.

Hasil penelitian ini mendukung hasil penelitian Suhardjanto (2008), Suhardjanto dan Permatasari (2010), Akhtarudin (2010) yang menunjukkan tidak adanya pengaruh proporsi Dewan Komisaris Independen terhadap pengungkapan lingkungan. Tetapi temuan ini bertentangan dengan penelitian Sun (2009), Salama (2010), Muthaher (2010) yang menemukan bahwa dengan adanya dewan komisaris independen, pengelolaan perusahaan lebih efektif dan dapat meningkatkan pengungkapan sosial dan lingkungan. Apabila jumlah komisaris independen semakin dominan, maka power dewan komisaris untuk menekan manajemen agar meningkatkan kualitas pengungkapan lingkungan (Haniffa dan Cooke, 2002) tidak terbukti pada penelitian ini.

c) Variabel jumlah rapat dewan komisaris (RAPAT_DK)

Variabel jumlah rapat dewan komisaris memiliki nilai signifikansi 0,18 lebih besar dari taraf signifikansi 0,05. Hal ini menunjukkan bahwa jumlah rapat dewan komisaris terbukti tidak berpengaruh positif signifikan terhadap pengungkapan lingkungan. Dengan demikian, hipotesis ketiga (H3) yang menyatakan bahwa jumlah rapat dewan komisaris terhadap pengungkapan lingkungan dapat diterima .

Dalam rangka menjalankan tugasnya, dewan komisaris mengadakan rapat-rapat rutin untuk mengevaluasi kebijakan-kebijakan yang diambil oleh dewan direksi dan implementasinya. Rapat dewan komisaris merupakan suatu proses untuk pengambilan suatu keputusan mengenai kebijakan perusahaan dan media komunikasi, koordinasi diantara anggota-anggota dewan komisaris dalam menjalankan tugasnya sebagai pengawas menejemen. Rapat dewan komisaris belum sesuai dengan harapan,

kemungkinan rapat yang diselenggarakan didominasi anggota komisaris independen untuk kepentingan pribadi atau kelompoknya sehingga kurang mengakomodir kepentingan perusahaan (Muntoro, 2006).

Hasil ini tidak sesuai dengan hasil penelitian Xie et.al (2003) yang menbuktikan bahwa semakin sering 
Dewan Komisaris bertemu atau mengadakan rapat, maka akrual kelolaan perusahaan semakin kecil. Dengan semakin seringnya para anggota dewan komisaris mengadakan rapat mendorong efektifnya fungsi pengawasan termasuk terhadap pengungkapan sisial dan lingkungan, maka pengungkapan lingkungan yang dilakukan perusahaan juga akan semakin luas. Hasil ini kembali mendukung hasil penelitian Suhardjanto dan Permatasari (2010) yang menyatakan bahwa rapat Dewan Komisaris tidak berpengaruh terhadap pengungkapan lingkungan.

d) Variabel jumlah komite audit (KA)

Jumlah komite audit memiliki tingkat signifikansi 0,125 lebih besar dari taraf signifikansi 0,05. Hal ini menunjukkan bahwa jumlah komite audit tidak terbukti berpengaruh positif terhadap pengungkapan lingkungan. Dengan demikian, hipotesis keempat (H4) yang menyatakan bahwa jumlah komite audit terhadap pengungkapan lingkungan tidak dapat diterima.

\section{Dalam Keputusan Ketua}

Bapepam Nomor Kep-29/PM/2004 yang termuat dalam peraturan Nomor IX.I.5 disebutkan bahwa Komite Audit yang dimiliki oleh perusahaan minimal terdiri dari tiga orang, dimana sekurangkurangnya 1 (satu) orang berasal dari komisaris independen dan 2 (dua) orang anggota lainnya berasal dari luar emiten atau perusahaan publik. Jumlah anggota komite audit harus disesuaikan dengan kompleksitas perusahaan dengan tetap memperhatikan efektifitas dalam pengambilan keputusan. Dengan dipatuhinya ketentuan ini diharapkan membantu sistem perusahaan dengan baik dan penyampaian informasi termasuk pengungkapan lingkungan sesuai harapan stakeholder.

Dalam penelitian ini berapapun jumlah anggota komite audit belum dapat dijadikan mekanisme pengendalian manajemen yang efektif. Rerata jumlah anggota komite audit lebih dari 3 orang berarti bahwa perusahaan sudah memenuhi ketentuan, tetapi jumlah ini tidak mempengaruhi pengungkapan lingkungan. Hal ini kemungkinan perusahaan hanya sekedar memenuhi aturan saja tanpa memperhatikan ukuran perusahaan dan efektifitas kerja komite audit.

Keberadaan komite audit dapat mempengaruhi pengungkapan yang dilakukan perusahaan secara signifikan dibuktikan oleh penelitian yang dilakukan oleh Ho dan Wong,(2001), Collier (1993) menyatakan bahwa keberadaan komite audit membantu menjamin pengungkapan dan sistem pengendalian akan berjalan dengan baik. Penelitian ini tidak sejalan dengan penelitian Ho dan Wong (2001), Barako, et.al (2006), Rouf (2008) tentang keberadaan komite audit berpengaruh terhadap pengungkapan sosial dan lingkungan.

e) Variabel proporsi komite audit independen, (PROP_KAI)

Proporsi komite audit independen memiliki nilai signifikansi 0,041 lebih kecil dari taraf signifikansi 0,05. Hal ini menunjukkan bahwa proporsi komite audit independen terbukti berpengaruh positif signifikan terhadap pengungkapan lingkungan. Hipotesis kelima yang menyatakan, proporsi komite audit independen berpengaruh terhadap 
pengungkapan lingkungan diterima. (Ha5 diterima).

Sesuai Surat Edaran dari Direksi PT Bursa Efek Jakarta No. SE008/BEJ/12-2001 tanggal 7 Desember 2001, salah satu syarat keanggota komite audit berasal dari pihak eksternal yang independen. Pihak eksternal adalah pihak di luar perusahaan tercatat yang bukan merupakan komisaris, direksi, maupun karyawan dari perusahaan tersebut. Pihak independen merupakan pihak di luar perusahaan tercatat yang tidak memiliki hubungan usaha dan hubungan afiliasi dengan perusahaan tercatat maupun dengan komisaris, direksi, pemegang saham utamanya. Dengan independensinya ini komite audit diharapkan mampu memberikan pendapat profesional secara bebas sesuai dengan etika profesionalnya dan memastikan laporan keuangan disajikan secara wajar sesuai dengan prinsip akuntansi yang berlaku umum.

Hasil penelitian ini bertentangan dengan penelitian yang dilakukan oleh Sun, et.al (2010), Nasir, et. al (2001), Suhardjanto dan Permatasari (2010). Penelitian ini membuktikan bahwa proporsi komite audit independen berpengaruh secara positif dan signifakan terhadap pengungkapan lingkungan.

f) Variabel jumlah rapat komite audit (RAPAT_KAI)

Variabel jumlah rapat komite audit memiliki nilai signifikansi 0,036 lebih kecil dari taraf signifikansi 0,05, dengan koefisien negatif. Hal ini menunjukkan bahwa jumlah rapat komite audit berpengaruh signifikan terhadap pengungkapan lingkungan. Rapat komite audit berpengaruh secara negatif terhadap pengungkapan lingkungan. Dengan demikian, hipotesis keenam (H6) yang menyatakan bahwa jumlah rapat komite audit berpengaruh positif signifikan terhadap pengungkapan lingkungan tidak dapat diterima.

Berdasarkan keputusan ketua Bapepam Nomor Kep-24/PM/2004 dalam Peraturan Nomor IX.I.5 disebutkan bahwa komite audit mengadakan rapat sekurang-kurangnya sama dengan ketentuan minimal rapat dewan komisaris yang ditetapkan dalam anggaran dasar perusahaan. Variabel jumlah rapat komite audit berpengaruh negatif terhadap pengungkapan lingkungan. Hal ini kemungkinan rapat yang dimaksudkan untuk mendukung kepentingan perusahaan diarahkan untuk mencapai kepentingan pribadi atau golongan. Kemungkinan lain adalah kompetensi anggota komite audit kurang memadai. Penelitian ini hanya meneliti jumlah anggota komite audit, proporsi komite audit independen, dan jumlah rapat. Untuk menjadikan fungsi audit yang efektif perlu diteliti juga kompetensinya.

f). Ukuran perusahaan

Variabel ukuran perusahaan memiliki nilai $\mathrm{t}$ sebesar 1.282 dengan tingkat signifikansi 0.071 lebih besar dari taraf signifikansi 0,05 . Hal ini menunjukkan bahwa ukuran perusahaan terbukti berpengaruh positif signifikan terhadap pengungkapan lingkungan perusahaan pada taraf signifikasi 0.1.

Banyak penelitian tentang pengaruh ukuran perusahaan terhadap pengungkapan lingkungan. Penelitian Rouf (2010), Buniamin (2008), Akhtarudin (2009), Suhardjanto (2008), 
Suhardjanto dan Permatasari (2010) membuktikan bahwa ukuran perusahaan berpengaruh positif signifikan terhadap pengungkapan sosial dan lingkungan.

Dalam penelitian ini variabel ukuran perusahaan terbukti mempunyai pengaruh sebagai variabel kontrol untuk mendukung pengaruh variabel bebas (corporate governance) terhadap pengungkapan lingkungan.

g) Tipe Perusahaan

Variabel tipe perusahaan memiliki nilai signifikansi $0,081 \quad(8,1 \%)$ yang berarti berada di atas taraf signifikansi $0,05(5 \%)$. Hal ini menunjukkan bahwa tipe industri terbukti berpengaruh secara positif pada level signifikansi 10\% terhadap pengungkapan lingkungan.

Tipe industri merupakan prediktor yang baik untuk pengungkapan informasi lingkungan hidup perusahaan. Perusahaan yang berpotensi terhadap penurunan kualitas lingkungan hidup akan mendapat sorotan publik yang lebih besar dengan meminta informasi tentang lingkungan lebih dari perusahaan yang secara alami tidak menimbulkan polusi. (Suhardjanto dan Miranti, 2009).

\section{KESIMPULAN DAN SARAN Kesimpulan}

Setelah dilakukan pengujian dan analisis yang dilakukan dalam penelitian ini, dapat diambil kesimpulan sebagai berikut:

1. Variabel proporsi anggota komite audit independen tidak berpengaruh terhadap pengungkapan lingkungan.

2. Jumlah rapat komite audit tidak berpengaruh terhadap pengungkapan lingkungan.
3. Jumlah anggota dewan komisaris tidak berpengaruh terhadap pengungkapan lingkungan.

4. Proporsi anggota dewan komisaris independen tidak berpengaruh terhadap pengungkapan lingkungan.

5. Jumlah rapat dewan komisaris, tidak berpengaruh terhadap pengungkapan lingkungan.

6. Jumlah anggota komite audit tidak berpengaruh terhadap pengungkapan lingkungan.

\section{Saran}

Berdasarkan hasil penelitian dan pembahasan sebelumnya dapat ditarik beberapa saran sebagai berikut:

1. Bagi manajemen diharapkan lebih lengkap dalam mengungkapkan kegiatan kegiatan yang berhubungan dengan lingkungan dalam laporan tahunannya.

2. Bagi pemerintah dan IAI diharapkan mampu merumuskan suatu kebijakan untuk menjadikan pengungkapan lingkungan sebagai sebuah mandatory disclosure mengingat rendahnya tingkat pengungkapan lingkungan.

3. Penelitian selanjutnya diharapkan menggunakan periode pengamatan yang lebih lama sehingga akan memberikan kemungkinan yang lebih besar untuk memperoleh kondisi yang sebenarnya serta menambah jumlah sampel.

4. Penelitian selanjutnya diharapkan dapat menambahkan atau menggunakan variabel lain untuk menemukan suatu model standar pendugaan pengungkapan lingkungan. 


\section{DAFTAR PUSTAKA}

Abdullah, S.N., N.R. Mohamad and M. Z. Mokhtar. 2001. Board Independence, Ownership And CSR Of Malaysian Large Firms.

Akhtaruddin, M., M.A. Hossain, M. Hossain, \& Y. Lee. 2009. Corporate Governance and Voluntary Disclosure in Corporate Annual Reports of Malaysian Listed Firms, The Journal of Applied Management Accounting Research, Vol.7, Number1.

Almilia, L. S. dan D. Wijayanto. 2007. Pengaruh Evironmental Performance dan Environmental Disclousure terhadap Economic Performance. Proceedings The 1st Accounting Conference STIE Perbanas Surabaya: 1

Anggraini, Fr. R. R. 2006. "Pengungkapan informasi sosial dan faktor-faktor yang mempengaruhi pengungkapan informasi sosial dalam laporan keuangan tahunan (Studi empiris pada perusahaan-perusahaan yang terdaftar Bursa Efek Jakarta)". Makalah disampaikan pada Simposium Nasional Akuntansi IX, Padang, 23-26 Agustus 2006.

Badan Standardisasi Nasional. 2005. Sistem Manajemen Lingkungan Persyaratan dan panduan Penggunaan, SNI 19-14001-2005.
Barako, D.G., P. Hancock, H. Y. Izan. (2006), Factors influencing voluntary corporate disclosure by Kenyan companies, Corporate Governance: An International Review 14 (2): 107-125.

Beck, A.C., D. Chambell, P.J. Shrives, (2010). "Enrichment and rehersal of the method in a British-German context". The British Accounting Review 42 (2010): 207-222.

Belkaoui, A. and P.G. Karpik. 1989. Determinants of the Corporate Decision to Disclose Sosial Information. Accounting, Auditing and Accountability Journal 2 (1): 36- 51.

Buniamin, S., B. Alrazi, N.H. Johari and N. R. Abdrrahman., 2008. An Investigation of the Association between Corporate Governance and Environmental Reporting in Malaysia, Asian Journal of Business and Accounting, 1(2)

Dulacha, G.B. (2006). Relationship between Corporate Governance attributes and Voluntary Disclosure in Annual Reports: The Kenyan Experience. Financial Reporting, Regulation and Governance 5 (1):....

Ghozali, Imam, Aplikasi Analisis Multivariate dengan Program IBM SPSS 19, Badan Penerbit Universitas Diponegoro, 2011.

Haniffa, R.M., Cooke, T.E., (2005). The Impact Of Culture And Governance On Corporate Social 
Reporting, Journal of Accounting and Public Policy 24 : 391-430

Ho, S. M., K.S. Wong, 2001. A Study Of Relationship Between Corporate Governance Structures And The Extent Of Voluntary Disclosure. Journal of International Accounting, Auditing \& Taxation $10: 139-156$.

Indonesian Ministry of Environment. Database Nasional Sertifikasi ISO 14001. www.menlh.co.id

Komite Nasional Kebijakan Governance. 2007. Pedoman Umum Good Corporate Governance Indonesia 2006. Jakarta.

Khomsiyah, Hubungan Corporate Governance Dan Pengungkapan Informasi : Pengujian Secara Simultan. Makalah disampaikan pada Simposium Nasional Akuntansi VI, Surabaya, 16 - 17 Oktober 2003.

Mobus, J. L. (2005). Mandatory Environmental Disclosure in Legitimace Theory Context. Accounting, Auditing \& Accountability Journal, 18(1): 492-517

National Committee On Governance. 2006. Indonesian's Code of GCG.

Rouf, Md. A. 2010. Corporate Characteristics, Governance Attributes And The Extent Of Voluntary Disclosure In Bangladesh, Asian Journal of Management Research. Online Open Access publishing platform for Management Research. Review Article ISSN 2229 - 3795

Said, Roshima, Yuserrie Hj. Zainuddin dan Hasred Haron. 2009. "The Relationship Beetween CSR and CG Characteristic in Malay". SRJ, Vol. 5. No. 2: 212 - 226.

Scott, W. R. (2006). Financial Accounting Theory. New Jersey: Prentice-Hall International, Inc.

Sembiring, E., 2005. Karakteristik Perusahaan dan Pengungkapan Tanggung Jawab Sosial : Studi Empiris pada Perusahaan yang Tercatat Di Bursa Efek Jakarta. Simposium Nasional Akuntansi VIII.

Suhardjanto, D., Permatasari, D. N., 2010. Pengaruh Corporate Governance, Etnis, dan Latar Belakang Pendidikan Terhadap Environmental Reporting Index. Vol. 13. No. 1:63-77.

Suhardjanto, D., Miranti, L., 2009. Praktik Penerapan Indonesian Environmental Disclousure:Studi Empiris pada Perusahaan Listing di BEI. Jurnal Bisnis dan Ekonomi. Vol. 14. No. 2:151-164.

Suhardjanto, D., 2008. Environmental Reporting Practices: an Evidence From Indonesia. Jurnal Akuntansi dan Bisnis. Vol. 8 (1):33-46

Sekaran, Uma. (2003). Research Methods For Business (4th ed.). New York: John Wiley \& Sons, Inc 
Sun, N., A. Salama, K. Hussainey, M.

Habbash, 2010. Corporate

Environmental Disclosure,

Corporate Governance and

Earnings Management.

Forthcoming, Managerial

Auditing Journal.

Suratno I, Darsono, Mutmainah S,

Pengaruh Environmental

Performance terhadap

Environmental Disclosure dan

Economic Performance, SNA 9

Padang, 23-26 Agustus 2006

Surya, I. dan I. Yustiavanda. 2006.

Penerapan Good Corporate

Governance: Mengesampingkan

Hak-Hak Istimewa Demi

Kelangsungan Usaha, Jakarta:

Prenada Media Group.

Suwardjono. 2005. Teori Akuntansi:

Perekayasaan Pelaporan

Keuangan. Yogyakarta: BPFE.

Undang-Undang Republik Indonesia No.

44 Tahun 2007 tentang Perseroan

Terbatas.

$\underline{\text { www.idx.co.id }}$

www. benefita.com 